\title{
Birocco, Carlos (2017). La vara frente al bastón. Cabildo y cabildantes en Buenos Aires (1690-1726). Rosario: Prohistoria, 246 p.
}

Guillermo O. Quinteros

Centro de Historia Argentina y Americana, Facultad

de Humanidades y Ciencias de la Educación,

Universidad Nacional de La Plata, Instituto de

Investigaciones en Humanidades y Ciencias Sociales/

CONICET, Argentina

Recepción: 03 Marzo 2020

Aprobación: 15 Julio 2020

Publicación: 13 Noviembre 2020

Cita sugerida: Quinteros, G. (2020). [Revisión del libro La vara

frente al bastón. Cabildo y cabildantes en Buenos Aires

(1690-1726) por C. Birocco]. Anuario del Instituto de Historia

Argentina, 20(2), e130. https://doi.org/10.24215/2314257Xe130

Desde mediados de la década de 1990 conocemos los numerosos artículos, capítulos de libros, ponencias, etc. de Carlos Birocco, fruto de sus pacientes investigaciones referidas a diversos aspectos de la sociedad porteña y de su campaña durante los siglos XVII y XVIII. Esta muy breve alusión a su labor explica -al menos en parte-la solidez del libro que comento.

Con algunas modificaciones, este texto es el resultado de su tesis de Doctorado, defendida en el año 2016. Como el mismo autor lo explica, versa sobre una cuestión que siempre lo inquietó: la transición dinástica de los Habsburgo a los Borbones en el Río de la Plata, en sus administraciones. El libro está dividido en nueve capítulos, cada uno de los cuales desarrolla objetivos muy claros y precisos con abundante información.

El comienzo, en el que ubica al lector en una Buenos Aires que ya no existe y en confrontación con Colonia de Sacramento, es de lectura fácil y amena. Luego ofrece una detallada descripción del concepto de ciudad bajo la Monarquía hispánica de principios del s. XVIII, para explicar que los ayuntamientos tenían la capacidad de autorregulación y autogobierno, razón por la cual no solo representaban el poder político sino también jurídico. Es así que los cabildantes eran la encarnación de la vara a través de la cual se impartía la justicia que, 
a escala mayor, detentaba el monarca. Birocco se empeña en no dejar nada librado a la especulación del lector y por eso explica el cuándo, el dónde, el qué, el quién y el para qué.

Se trata de un estudio sobre las oligarquías urbanas, al que el autor incorporó el enfoque jurisdiccionalista, lo cual le ha permitido dialogar con grupos de investigadores de diversas universidades, quienes actualmente utilizan tales conceptos. En ese sentido, la bibliografía utilizada resulta pertinente y muy actualizada.

El grupo estudiado es la dirigencia concejil vinculada al gobierno de la ciudad en toda la jurisdicción de la misma. Si bien se refiere a décadas anteriores, el período en el que se concentra se extiende desde 1690 a 1726, es decir, entre el último gobernador designado por los Habsburgo para el Río de la Plata y la fundación de la ciudad de Montevideo. La región cobró alguna importancia desde la fundación de Colonia de Sacramento en 1680 puesto que fue percibida como una amenaza de Portugal y su consecuencia fue la instalación de un destacamento de unos 800 soldados. El interés de la Corona se puso de manifiesto en el nombramiento de funcionarios no improvisados para su destino en Buenos Aires.

Los gobernadores que llegaron a Buenos Aires gozaban de una vasta experiencia militar así como de poder de decisión propio, en parte como resultado de las grandes distancias que separaban a esta región de la sede del Virrey del Perú del cual dependían. Señala Birocco que "El escaso empeño que pondría la Corona en moderar ese poder discrecional serviría a esos gobernadores para avanzar sobre las facultades del cabildo y despojarlo del control de uno de los pocos recursos con que contaba: el monopolio de la venta de cueros en el puerto. Así comenzó un prolongado enfrentamiento en que el monarca no mediaría sino tardíamente: confrontación que vista desde el plano simbólico tuvo de un lado al Bastón, empuñado por los gobernadores como emblema de su poderío militar, y del otro a la Vara, detentada por los magistrados del cabildo” (pp. 16-17).

El autor se remonta más atrás para explicar cómo, de manera lenta, se va formando una elite al mismo ritmo que crecían las actividades portuarias. Ello formó parte del proceso de transformación que llevó a los conquistadores a convertirse en vecinos. Se inició de ese modo la formación de un cuerpo político, al mismo tiempo que, desde la segunda década del s. XVII, Buenos Aires comenzó a cambiar su fisonomía como ciudad portuaria. En efecto, ello fue posible a partir de la entrada en acción de comerciantes contrabandistas, quienes establecieron circuitos comerciales tendientes a perdurar y generar riqueza, e intereses económicos difíciles de eludir.

Sin embargo, para algunos sectores sociales la vida en Buenos Aires no era del todo fácil; por ejemplo, el de los hombres de armas. El salario de los militares del fuerte dependía del real situado y por tanto, si las remesas se atrasaban -lo cual era muy habitual- su sustento dependía de lo que hicieran por fuera de su profesión. Es así que hacia finales del s. XVII varios de estos militares se dedicaron al comercio minorista, y simultáneamente emplearon estrategias sociales de apertura para construir lazos de sangre con familias locales. Con el tiempo, unieron a sus hijas tanto con los viejos como con los nuevos miembros de la elite. Señala Birocco que las principales familias de Buenos Aires no poseían una genealogía profunda, pero en cambio podían exhibir una importante red de relaciones horizontales. Dicha red estuvo compuesta por vecinos propietarios de tierras, sargentos, capitanes, comerciantes, y varios inmigrantes peninsulares no pertenecientes a las clases privilegiadas, entre otros.

La buena práctica del historiador lleva al autor a realizar una pintura del contexto histórico, social, político y económico, y a explicar con claridad y sencillez cómo se llegó a la Buenos Aires de 1690, cuál era la situación en que se encontraba esa sociedad cuando se nombró al último de los gobernadores bajo el imperio de los Habsburgo.

A propósito de la transición y luego de ahondar en la problemática de la venalidad de los cargos, en la manera en que se compraban y, luego, en los nombres de quienes se hicieron con los mismos, Birocco discute algunos supuestos y afirmaciones aún vigentes. El aserto de que bajo el gobierno de los Habsburgo había una tendencia hacia la venalidad, mientras que con los Borbones dicha tendencia revirtió hacia la burocratización, es para el autor inexacto. Entonces comprueba que entre 1630 y 1726, independientemente de que algunos pudieron comprar su cargo, todos los gobernadores contaban con una foja de servicios importante o fueron 
militares con una vasta experiencia y solo los últimos llegaron al cargo como producto de la venalidad. Agustín de Robles, quien sucedió al gobernador Herrera, fue uno de ellos, y asumió el cargo en el ayuntamiento los primeros días de abril de 1691. La llegada a Buenos Aires de Robles con su familia, el establecimiento de sus relaciones con personajes influyentes como Miguel de Riblos y su propia pericia para ver en medio de circunstancias desgraciadas una oportunidad de negocio, son descriptas por el autor de manera detallada. Mientras que el lector queda envuelto en una atractiva trama de relaciones políticas, Birocco pone en evidencia las luchas facciosas por el poder: el gobernador adoptaba medidas y asumía actitudes sociales, políticas y económicas con la finalidad de granjearse el apoyo de los miembros influyentes de la elite. Por su parte, los cabildantes afrontaban sus propias internas en tanto que sostenerse en sus cargos les permitía mantener una alta cuota de prestigio material y simbólico. Luego, por si fuera poco, explica la lucha entre la vara y el bastón, es decir, entre los miembros del Cabildo y el gobernador.

Una de las fortalezas más importantes de este trabajo radica en que el lector siempre está ubicado en un vasto territorio dentro del cual Birocco lo sitúa y conduce, porque las guerras a las que hace referencia transcurren tanto en la Sala Capitular, como en un recinto del fuerte o en el despacho real. Esto es así porque a pesar de referirse a un ámbito claramente porteño, los problemas que se les presentan a los protagonistas de esta historia y las cuestiones que afronta el historiador, son parte constitutiva de ese todo que era el Imperio español.

No obstante lo planteado, el libro posee una cuantiosa información de índole local, producto de un trabajo muy importante del autor con fuentes de primer orden. En este sentido -sobre todo desde el capítulo 3 en adelante- el tratamiento y análisis de esta información puede ser muy bien aprovechado por especialistas. Cabe destacar que la lectura sigue siendo dinámica, amena y al alcance de cualquier lector, pero conforme desarrolla sus argumentos, Birocco discute con autores, señala sus disidencias, así como se apoya en los resultados de las investigaciones de otros historiadores y acuerda con ellos. Lo puede hacer por el amplio conocimiento de los temas que trata y por el cuidado que ha puesto en los detalles y en la exposición de la información recogida, cuestiones que lo llevan además a establecer categorías y criterios de clasificación propios.

En consecuencia, un lector poco avisado sobre las problemáticas del poder en la Buenos Aires de fines del siglo XVII y principios del XVIII puede encontrar en este libro una narrativa que lo llevará a interesarse por saber más de lo que se plantea en las primeras páginas. Se trata de literatura histórica, lo cual significa mucho en estos tiempos de escasa claridad conceptual y de poco cuidado por la escritura. Para profesores y estudiantes que abordan el estudio de aquella época, la información sobre cómo se componía la planta del Cabildo (sobre todo sus cargos); quiénes eran los integrantes; cómo se elegían; cuáles eran sus actividades y sus atribuciones, así como el rol jugado por los cabildantes en el mayor o menor grado de progreso de la ciudad y su campaña, es muy clara e indispensable para comprender el funcionamiento de una ciudad dentro del Imperio español.

Por último, lo dicho: este es también un libro para entendidos. 